\title{
Being Virtuous and Prosperous: SRI's Conflicting Goals
}

(Principles of Responsible Investment Academic Conference, Ottawa, October 2009)

\section{Benjamin J. Richardson, Professor, Osgoode Hall Law School, York University Wes Cragg, Professor, Schulich School of Business, York University}

\begin{abstract}
What is the purpose of SRI? Is its goal to frame investment with ethical values? Or is it goal to persuade investors that ethical investment is an effective, perhaps the most effective way to achieve economic objectives, or more specifically maximize the value of their investments? This paper argues that there are significant tensions between these goals, and that SRI should not allow the pursuit of higher investment returns to prevail over an ethical agenda of promoting ethical and socially responsible business practices..

The discourse on SRI has changed dramatically in recent years to the point where its capacity to promote social emancipation, sustainable development and other ethical goals is in jeopardy. Historically, SRI was a boutique sector of the market dominated by religious-based investors who sought to invest in accordance with the tenets of their faith. From the early 1970s, the aspirations of the SRI movement morphed significantly in the context of the divestment campaign against South Africa's apartheid regime. No longer were social investors satisfied just to avoid profiting from immoral activities; instead, they also sought to change the behaviour of others.

It was not until the late 1990s that the mainstream financial sector, particularly institutional investors, began to treat SRI as a legitimate investment strategy. However, with the "mainstreaming" of SRI, its aspirations have shifted from advocating ethics as an investment criterion to advocating a business case approach to responsible investment. In this guise, SRI is championed primarily as a means to be prosperous rather than virtuous. This approach to SRI risks marginalizing social and environmental values if they are not be shown to investors to be "financially material".

Business case SRI is a problematic benchmark for several reasons: often there is a countervailing business case for financing irresponsible activities, given the failure of markets to capture all social and environmental externalities; secondly, even if investors care about such concerns, there may be no means of financially quantifying their significance for investment purposes; and, thirdly, even if such factors can be financially quantified, they may be deemed to be such long-term financial costs or benefits that they become discounted and ignored.

The ethics case for SRI and ethical business practices more generally takes the view that both investors and the companies they fund have ethical responsibilities that trump the simple pursuit of profits. Investment should be grounded on an ethical foundation. Relying on a purely voluntary approach to ethical investment, however, may not be enough. To keep ethical investment ethical will likely require institutionalizing new norms and governance standards, in such domains as reforming fiduciary duties and the internal governance of financial organizations. SRI's own codes of conduct including the UNPRI have yet to demonstrate the robustness to move the financial community beyond a business-as-usual approach governed primarily by a pursuit of maximizing investment returns.
\end{abstract}




\section{The Conflicting Goals of SRI}

The movement for socially responsible investment (SRI), which was once more commonly known as "ethical investment", increasingly instrumentalizes ethics. Historically, it was a different story. The anti-slavery campaigns of Quakers in the 1700s and the financial sanctions against South Africa's apartheid regime during the 1970s and 1980s were motivated by unadulterated ethical concerns rather than the prospect of financial reward. While SRI was historically ignored by mainstream financial institutions such as pension funds and investment banks, their increasing endorsement of it in the last decade has been accompanied by changes in the terminology, methods and meaning of SRI. These investors pitch their case for acting responsibly on business grounds, on the assumption that SRI may give investors a financial edge. However, some significant conflicts may arise where the justification for ethical investment is increased financial returns. Sometimes there is no business case for acting ethically. What then?

In this new mode, SRI may garner attention only to the extent that investors see social or environmental issues as "financially material" - in other words, when such issues pose tangible financial risks or opportunities. While this business case approach to SRI is attracting more adherents to the movement, it may merely tinker with addressing the underlying problems such as pollution, poverty and human rights abuses. The prevailing view among many contemporary investors is that the only purely "ethical” issues are the traditional concerns of the faith-based investors, such as tobacco or gambling. Otherwise, social and environmental problems are deemed just to be phenomenon with differing financial implications.

Yet, ethical investment should no longer be a discretionary choice for financiers, to follow only if there is a compelling business case. All investors, whether or not they profess to follow SRI, should act within a framework of ethical values. In a world facing grave ecological problems and social injustices, the financial sector must shoulder some of the responsibility to mitigate these problems (Richardson, 2008). Private investment that has public costs must account for such impacts. Indeed, for many reasons, the financial sector should provide ethical leadership. The sector, which includes banks, pension plans, mutual funds and various other types of financiers, performs many economically crucial functions including the raising and distributing of capital, and 
managing financial risks. The 2008 collapse of the sub-prime mortgage market in the United States, which reverberated worldwide far beyond the banking sector, shows how pivotal the financial economy is to the health of the productive economy (Soros, 2008). The financial markets are also where "wholesale" decisions concerning future development, and thus eventual environmental pressures, arise. These pressures, once warned the United Nations’ Millennium Ecosystem Assessment Board (2005: 5), are "putting such strain on the natural functions of the Earth that the ability of the planet's ecosystems to sustain future generations can no longer be taken for granted”.

Such problems pose significant ethical challenges to humankind, whose resolution will require redefining societal measurements of value and establishing new reasons to act. While business case SRI, as with any investment choice, may be viewed as reflective of some underlying ethical position, such as utilitarianism, it does not reflect credible ethical standards that can promote sustainability and social emancipation in the public interest over the long-term. Market incentives can engender changes only within a rather limited framework that appeals to actors' self-interest. Many environmentalists contend that only through a new ethical paradigm can humanity evolve sustainably and live in harmony with nature (Devall and Sessions, 2001).

In 1992, some 1700 international scientists proclaimed their "Warning to Humanity”, and called for "[a] new ethic ... towards discharging our responsibility for caring for ourselves and for the earth” (Union of Concerned Scientists, 1992). Many others agree that progress toward sustainability depends upon challenging the anthropocentric and instrumental values of industrialised, capitalist society (Light and Rolston III, 2003; Soskolne, 2007). Any other solution would likely just respond to the symptoms, rather than the root causes, of unsustainable development. An ethical view helps decision-makers to understand human behaviour and set standards that provide grounds to act when financial incentives are absent or insufficient.

Given that mainstream financial actors have long chosen to ignore or downplay ethical investment, why would they choose to do so now? How might they be persuaded to act differently? Lofty rhetoric for more enlightened behaviour on its own will be unlikely to inspire change voluntarily. There are too many countervailing pressures in a competitive market to induce widespread ethical transformation. Thus, we need new kinds of policy instruments to help inculcate ethical behaviour. Law alone, of course, is 
not always enough. Whether the law relies on carrots or sticks to induce compliance, the legal system has long been shown to suffer from significant limitations as a means of engineering social change (Teubner, 1987). Law must work in unison with other means of influence. Ethical arguments and moral suasion can help give investors and other business actors further reasons to behave lawfully and responsibly.

This article explores these ethical arguments and the concomitant legal strategies that are necessary in order to restore an ethical basis to all investment. The following section theorizes how the social and environmental responsibilities of financial institutions should be conceived. Later, the article examines the type of legal reforms, focusing on the fiduciary duties of investment institutions. While we do not dispute that financial institutions are economic actors interested in being prosperous, that legitimate goal must be subservient to an overarching ethical framework of decision-making protected by law. In discussing the ethical challenges of SRI, we will often characterize these challenges as one of achieving "sustainability” (Richardson, 2006), which has become a widely recognized term to describe the intertwined social and ecological goals of humankind.

\section{Theorizing the Ethical Responsibilities of Investors}

\section{The evolving private and public responsibilities of business}

Why should investors be guided as investors by ethical values? While there is significant literature that has theorized the moral responsibility and legal accountability of corporations and their managers in regard to human rights, labour standards, environmental protection and other ethically salient issues, the position of investors in those corporations has been relatively neglected. They are, however, quite closely intertwined positions given that corporations represent the primary means by which investors make money, such as through their roles as shareholders, bondholders or lenders.

Perhaps the greatest obstacle to accomplishing ethical investment is the currently dominant management dogma and theories of the firm that view the primary purpose of the publicly traded corporation as to maximize profits (Bainbridge, 2002: 419-29; Macey, 
1991). From the perspective of these theories, if profit maximization requires respect for human rights or stopping pollution, ostensibly there is no problem. If it does not, as sometimes occurs, then corporations presumably have an obligation to their shareholders not to allow human rights or environmental concerns to impede their profit-maximizing raison d'être.

This notion is a result of the particular evolution of the modern corporation. Historically, enterprises were typically granted authority to conduct business for the purpose of achieving some specific public goal. A notable example is the charter granted by the Crown to the Hudson Bay Company to develop Canada's northern regions (Moodie and Lehr, 2008). In the late $19^{\text {th }}$ century, the mercantile idea that corporations should be chartered only where their activities would advance public goods was replaced in many jurisdictions with a legislated framework requiring only that those people wishing to incorporate register their companies following a set of largely formal, and not particularly onerous, bureaucratic procedures. Thereafter, the primary obligation of corporations has come to be seen by many as to serve the interests of their shareholding investors.

Concomitantly, for much of the history of the modern corporation, especially since the Second World War, there has been what could be described as a tacit social contract in the industrialized world between the state and the private sector resulting in a de facto division of responsibilities. Safeguarding the environment and protecting human rights was allocated to government while the private sector was allocated primary responsibility for generating economic wealth (Cragg, 2000). The practical effect of this informal social contract has been to encourage many in the corporate world to disregard human rights or environmental protection as a corporate responsibility except where required to do so by law in the belief that responsibility for addressing these kinds of "non economic" concerns were the responsibility of governments to address. Concomitantly, references to "the invisible hand" of the market have been also advanced to counter the argument that business has obligations to advance public, as well as private, interests (Marris and Mueller, 1980). The assumption is that corporations are the most efficient means of generating wealth, and therefore they should be left to pursue the private interests of shareholders unfettered by concerns for the social or environmental 
impacts of their activities, which are a responsibility best left to the state (Clark, 1986: 20-21, 30-32).

In relation specifically to shareholders, bondholders or other types of investors, there is a further consideration that, in the context of a global economy, they may be too remote from the actions of a corporation to intervene effectively or efficiently. A fund manager in New York or London is likely to have little knowledge of the operations of a firm in a distant country, and which may also represent one of literally hundreds or thousands of companies in a large investment portfolio. It follows that it is possibly unrealistic to hold investors legally accountable or morally responsible for the social or environmental impacts of firms they finance beyond what is required by law and legally enforced or mandated by market forces. Given, as Immanuel Kant once pointed out, that “ought implies can”, investors surely must shown to be in a position to influence the operations of shareholder-owned corporations if they are to be held accountable (Kant, 1999: xliii).

However, these considerations are no longer, if ever they were, sufficiently persuasive grounds to deny the ethical responsibility of investors and the firms in which they invest to respect and promote ethical business practices with a view to promoting sustainability. To explain why, it is necessary to begin by examining the relationship between investors and society including its legal system.

The neo-classical canonical account of the firm is quite compatible with the view that financial institutions and corporations have an obligation to respect and obey the law, including laws relating to human rights or environmental protection. Indeed, Milton Friedman described the obligation to respect the law as one of the fundamental features of his theory of the firm (Cosans, 2009). However, the justification for the view that corporations, and their investors, have an obligation to obey the law is not clearly articulated by Friedman or other neo-classical theorists. This obligation, however, has connotations for the social responsibility of firms that are much broader than these theorists would concede.

Financial institutions such as banks and investment companies, as with regular corporations, are a legal artefact. They come into existence only where there is a legal framework that creates their institutional possibility. The law makes incorporation possible and creates the legal framework for trusts and other institutional templates that 
financial organizations utilize. The law also protects investors in companies through the rule of limited liability (Easterbrook and Fischel, 1985). In addition to clothing financiers with a legal personality, the legal system creates the conditions that enable markets to flourish, such as by establishing and protecting the property rights and contractual responsibilities of parties (Sunstein, 1991: 608). The legal system is also responsible for an extensive microcosm of rules and procedures that govern how financiers and corporations conduct their affairs in specific situations. These include licences to operate, permits to emit pollutants, and so on.

What is thus at stake is how best to ensure that economic activity contributes to the public good. It is not acceptable to justify the creation of the extensive national and international legal architecture that frames investment and corporate activity in today's troubled world on simply the right of individuals to invest and make as much money as possible. If the private sector is allowed to pollute and degrade the environment, leading to irreparable harms such as global warming or mass species extinction, its own future is surely also in jeopardy. Likewise, if societies are allowed to disintegrate into violence, widespread poverty and other hardships, business will be deprived of a milieu in which it can flourish. The private sector has therefore a significant implied interest in maintaining a healthy society and environment, operating under the rule of law, which makes its activities possible and profitable.

In addition to all these reasons why business should act in the public interest, business enterprises have stakeholders. In other words, the activities of banks, mutual funds and ordinary corporations impact on individuals and groups whose interests are thereby affected both negatively and positively. The activities of business thus give those they impact a stake in those activities. A substantial body of literature on stakeholder theory has thus explored the moral principles, and their legal manifestations, that bear on corporate activities as a result of this situation (Marjorie, 2001; Stout, 2002). Stakeholders, such as workers, local communities, consumers and the environment itself have a moral status that business managers must reckon with on moral grounds. Indeed, some legal commentators have argued that they also may have a legal status in corporate governance, as corporate managers "have always had some legal discretion (implicit or explicit) to sacrifice corporate profits in the public interest" and that "proper economic analysis does not prove this discretion is undesirable or even inefficient” (Elhauge, 2005: 
738-39). One reason for such discretionary authority is that, unlike corporate managers, shareholders may be too distant and insulated from the "social and moral sanctions" applicable to corporate conduct that can be costly to a firm if ignored (Elhauge, 2005: 740). Among financial institutions, bank managers lending to environmentally problematic projects would likewise have the discretionary authority to be responsive to these social and moral sanctions that arise from relationships with stakeholders..

It is necessary to pause here, in order to elaborate why financial institutions in particular should act ethically to promote sustainability, rather than just to treat this ethical imperative as one for the companies they invest in. Most fundamentally of all reasons, by profiting from the funding of companies engaged in environmentally degrading and socially harmful activities, financiers should share accountability. Capital financing is instrumental to development choices; that those who enable, and benefit from, those choices through financial investment must also share in the responsibility of resulting harms. Financial institutions evolved to mobilize capital to fund economic activity and thereby generate financial returns for investors. Anyone who has ever inquired at a bank about a personal loan, credit card or mortgage, will understand that financial institutions do not want their capital sitting around idly. Rather, money has to be actively managed and be reinvested to generate profit. This pervasive drive to put capital to use, to make more capital, invariably creates a process that fuels widespread social and environmental changes.

A further consideration in holding financiers accountable, indeed to higher standards than that applicable to the companies they fund, is because of the generally greater economic and environmental salience and impact of financial institutions. The recent sub-prime, mortgage lending crisis in the United States illustrates painfully how failings in one financial sector can ripple through the international economy producing much more devastating impacts (Soros, 2008). The financial sector contains propagation mechanisms that can amplify initial, small shocks throughout the economy. Thus, apart from any environmental effects attributable to the financial economy, many commentators have long argued that on traditional economic policy grounds, banks and other financiers should be controlled and monitored more closely (Heremans, 2006; Macey and O’Hara, 2003). 
Even in terms of their own self-interest, some financial institutions surely have pragmatic reasons to be socially responsible. Hawley and Williams (2000) argue that large institutional investors, which they describe as "universal owners" investing broadly across the economy, have self-interested reasons to take an interest in the health and long-term sustainability of the entire economy. This is because, as global, economy-wide investors, they have nothing to gain long-term by abetting behaviour by any one company that is profitable in the short-term but threatens harm to other parts of the economy or the natural resources on which its depends. Acting as a universal investor implies that what is an "externality" at the level of an individual company can result in a costly "internality" for an investor's global portfolio. A related reason for acting responsibly is that large institutional investors commonly hold assets on behalf of millions of individual investors across a large spectrum of society, who presumably share an interest in the health and well-being of the economy and its beneficiaries.

\section{Reallocating responsibilities between the state and the market}

What is crucially at issue, then, is not the end to be achieved of a socially just and ecologically sustainable world community, but the allocation and implementation of responsibilities among various economic actors and stakeholders for achieving that goal. An unchecked free market is certainly not capable of achieving that goal. The assumption that the pursuit of private economic interests will consistently generate substantial economic and other public benefits ignores the significant "collateral" social and environmental costs, which are typically borne by those who did not create them (McMurtry, 1998). However, recognition of an ethical imperative to act differently, even by companies in their public statements, has often not altered the underlying behaviour of business. Their ability to compete effectively in the marketplace, coupled with prevailing assumptions about their obligation to maximize profits, militates sharply against investors acting ethically. Not even so-called universal owners can necessarily make a difference; even if mindful to act responsibly, collective action problems remain. Institutional investors cannot easily coordinate their activities to constrain economic growth safely within the overall capacity of the biosphere. The market contains no mechanism to keep 
economic activity within the carrying capacity of the planet, such as by limiting carbon emissions to avoid climate change (Daly, 1992).

On the other hand, states also can lack the capacity to effectively govern the multifarious social and environmental externalities of the market (Sunstein, 1990; Teubner, 1998; Yeager, 1991). The techniques of the modern regulatory state, particularly coercive "command-and-control” approaches, have struggled to control these burdens. The dense maze of legal controls has tended to reach the point of diminishing marginal returns: the effectiveness of further regulation often being outweighed by the administrative costs and difficulties of ensuring compliance (Stewart, 2001: 30-31). Systems theory explains how the splintering of modern society into semi-autonomous "subsystems", such as the market and the legal sectors, hinders regulation of corporations and financiers. Because they are actors within a market subsystem, their behaviour is shaped primarily by the market's norms of exchange, competition, and profitability (Luhmann, 1995). Legal rules at odds with those norms will usually be resisted. Consequently, in recent years many countries have sought to govern the market through market-imitation economic incentives, such as pollution taxes or tradeable carbon emission allowances (United Nations Environment Programme, 2004). While this strategy has also helped to build the business case for SRI, it has not provided a comprehensive solution as economic policy instruments have usually required extensive “re-regulation” to be operationalized (Redgwell, 1997: 36).

Globalization has also greatly diminished the capacity of national governments to set and enforce meaningful social, economic and environmental standards (Falk, 1999; Sassen, 1996; Wolf, 2001). Globalization has not only encouraged the growth of large multinational corporations, some of whom control budgets that are larger than the budgets of most national states, it has also entailed the emergence of vast international financial markets that defy effective regulatory control (Alexander, Dhumale and Eatwell, 2006: 3). Much economic activity is now ultimately a result of the financing decisions of institutional investors, located in global financial hubs such as London or New York that are very distant to the productive economy in which actual corporate development takes place. Concomitantly, globalization has been accompanied by restrictions on the ability of nation states to set standards has been eroded by international free trade agreements and multilateral investment treaties. International competition for 
economic investment has fuelled what some have described as a "race to the bottom" or a "regulatory chill” in the quality, extent and enforcement of regulation (Kozul-Wright and Rowthorn, 1998). These conditions therefore require a reappraisal of the social contract between the state and the market in searching for a new approach to promoting sustainability.

One plausible alternative therefore is for the private sector to assume some degree of responsibility for ensuring that its activities generate public benefits, while sharing with the state some of the regulatory burden to promote ethical business practices. Underpinning the licence of investors to operate is the growing expectation that their activities will generate social benefits. The task is not an easy one, partly because of the diffused nature of the public goods and interests at stake.

A standard criticism of SRI or other forms of corporate social responsibility is how to define these ethical obligations with sufficient precision to hold the private sector measurably accountable (Watts, 2009). Some SRI issues involve deeply contested ethical issues, such as animal welfare, alcohol, casinos and fertility control. In the absence of an ethical consensus on such issues, either in society generally or within a specific investment fund, law-makers may have to be settle for procedural reforms such as obliging funds to allow their members to debate the ethical issues at stake and requiring greater transparency about investment policies and their justification. On the other hand, some SRI issues involve market failures where the problem is not that an activity is intrinsically objectionable, but the fact that there is too much of the activity occurring (e.g., emitting greenhouse gases, fishing, and cutting trees). Social agreement on controlling these activities is usually much more achievable, although there will of course be differences in determining how to do so and who should pay for corrective action. Thus, not all ethical concerns may be capable of being enunciated as clear normative obligations; some may need to be addressed indirectly through procedural reforms that at most facilitate public debate and better rationalization of decisions.

What then, should the private sector itself do to promote sustainability in a reallocation of responsibilities? Allowing it to regulate itself through voluntary codes of conduct such as the United Nations Principles of Responsible Investment is not likely to be sufficient. Unmonitored corporate commitments without sanctions for non-compliance are unlikely to improve corporate behaviour when they are costly to implement, 
something that corporate behaviour suggests is all too pervasive (Klein, 2000; Wood, 2006). Voluntary measures may even be introduced strategically to circumvent official regulation and thereby forestall meaningful change.

Alternatively, some believe that the profit-motive itself can be harnessed to give investors a powerful self-interest in promoting sustainability and to act charitably towards other stakeholders (Donaldson and Preston, 1995). Can a pragmatic, business case provide sufficient motivation for SRI? Are financial institutions likely to honour commitments to behave responsibly where risk reduction or enhanced profitability is unlikely to follow? The record in this respect is not encouraging. The following section examines the limitations of the business case approach to SRI.

\section{Business Case SRI}

While the SRI movement is seeking greater accountability of the financial sector for the environmental and social problems connected to the economic activities it funds, it is doing so in a manner that works largely within the existing analytical and normative framework of the financial economy (Jeucken, 2001; Labatt and White, 2002). The SRI sector comprises a diverse array of actors with similarly diverse aspirations and strategies, but it is now dominated by institutional and retail investors whose cues are primarily the financial costs and benefits of acting responsibly.

Thus, sustainability issues acquire significance to these investors primarily to the extent that they are perceivable as financially "material” (UNEPFI, 2004a). The tools of business case SRI include light-touch investment screens that reject only the most insidious firms (so as not to diminish significantly portfolio diversification and thus returns), polite engagement with corporate management, and more sophisticated analytical methods to assess the financial repercussions of corporate social and environmental behaviour. This approach has been endorsed by international SRI networks such as the United Nations Environment Program Finance Initiative (UNEPFI). Catering mainly to the institutional investment sector, UNEPFI explains in its report, Show Me the Money (2006: 4), that: "[t]he first - and arguably for investors the most important - reason to integrate $[\mathrm{SRI}]$ issues is, simply, to make more money ...”. In another UNEPFI report (2004b: 5), financial analysts are advised to demonstrate 
"material links to business value; ... [and] avoid moral arguments". Similarly, in the retail market catering to household investors, SRI funds are commonly marketed in the same manner as conventional portfolios for how they may generate higher returns and outperform the market (Brill, Brill and Feingenbaum, 1999).

Not all social investors, however, are so materially self-interested. Some religious investors continue to treat SRI as a matter of ethical necessity (Triolo, Palmer and Waygood, 2000: 26-53). The churches once spearheaded a divestment campaign against companies profiting from apartheid in South Africa. They continue to be the vanguard of change, such as through Interfaith Center for Corporate Responsibility's campaigns concerning climate change and environmental justice. ${ }^{1}$

Ethical investment may be approached from different conceptual frameworks. From the perspective of teleological ethics, SRI can be judged by its consequences, such as the promotion of sustainable development or the protection of human rights. Deontological ethics, by contrast, caters to investors who personally do not wish to profit from activities considered intrinsically unethical, such as gambling or pornography, or the abuse of human rights. Virtue ethics guide investors to examine corporate commitment to creating ethical business cultures. All three approaches lead investors to reject investments in companies that operate outside of the ethical frameworks they advocate without regard to forgone financial gains and promote investment in companies that operate with the ethical frameworks being advanced even where expected financial returns may be lowered..

In contrast, the dominant business case approach to SRI is traceable to theories of shareholder primacy that conclude that corporate managers, as do fund managers, pension fund trustees and other investment decision-makers, have economic and legal obligations to maximize profits. These obligations flow from the fact that, as agents, managers, trustees and other business decision-makers have fiduciary obligations towards their beneficiaries, whether they be shareholders, pension plan members or the like (Langbein and Posner, 1980). With regard to other stakeholders, however, the only obligation is said to be to act strategically. The value of any such strategic thinking is its utility for the achievement of business objectives.

Can business drivers allow investors to reach the same decisions as ethicallymotivated investors? While respect for the environment or human rights often can have a 
pragmatic value to financial institutions, it can also be an impediment to profit maximization. Situations where pollution is tolerated or human rights are not respected can offer strategic advantages to investor corporations, such as reduced environmental management costs or lower wage rates (Slapper and Tombs, 1999: 167-70). Thus, acting responsibly can confer disadvantages as well as advantages. So, while the business case for SRI offers pragmatic reasons for ethical investment, it opens the door to pragmatic arguments for investing unethically. For financial institutions that profess to invest ethically but act strategically, the solution to avoid being embarrassed has been to take advantage of the lack of standardization in the SRI market. The laissez-faire market for SRI has allowed a fungible and superficial retail "ethics" to proliferate, where salesmanship and marketing tend to prevail over reflective moral deliberation. Indeed, the average SRI portfolio can be little different to a regular investment fund; a 2004 survey by the Natural Capital Institute concluded that "the screening methodologies and exceptions employed by most SRI funds allow practically any publicly-held corporation to be considered as an SRI portfolio company” (Hawken, 2004: 16).

Sometimes "reputational risks" to companies associated with unethical practices may trigger action. Given that somewhere between fifty to seventy percent of the business value of many large public companies is attributable to their brand name and goodwill, the risk of a sullied reputation should motivate ethical behaviour by high profile firms (Purcell, 2007). A World Resources Institute report (Herz, Vina and Sohn, 2007) argues that the business case approach can also motivate more respect for the poor and marginalised where financiers find that their projects need community consent and legitimacy. Nonetheless, reputational risks to investments do not provide a comprehensive solution. Sometimes the most disadvantaged groups or victims of pollution lack the means to publicize their plight. And some financiers or firms of low public visibility may not be particularly vulnerable to such reputational risks in the first place. Where a financier's concern is reputational risk, the professed commitment to act responsibly can thus amount to nothing more than good public relations.

There are further reasons why business case SRI is no assurance for meeting the challenges of sustainability. A primary blind-spot is that unless social and environmental issues are perceived to have tangible financial implications, investors may ignore them. Often they are perceived as too nebulous for workable financial quantification 
(McGeachie, Kiernan and Kirzner, 2005: 57). Values such as biodiversity or climate integrity cannot be captured by conventional financial accounting systems unless they give rise to specific expenses and income attributable to an individual organization (Goodman and Little, 2003). A further, related limitation is that while the SRI community increasingly argues that there is a "long-term” business case for investing responsibly on such issues as climate change, the problem is that market pressures to act for the shortterm can readily trump any perceived long-term costs and benefits that are discounted considerably. For example, the incentive system for fund managers on short-term contracts greatly hinders their willingness to move their focus beyond current performance and market valuations (Juravle and Alan Lewis, 2008: 290).

Just as the rationale to act ethically can also under different circumstances motivate unethical conduct, the decision to operate within the constraints of the law, including environmental or social regulation, will also be viewed by these investors strategically. While shareholder theorists including Milton Friedman accept that business managers have a responsibility to pursue their goals and objectives within the constraints of law, the proposition that they should do so has never been adequately rationalized. The answer presumably would be that failure to respect the law generates financial risks, which financial managers must avoid in order to maximize returns. Yet, if shareholder theories imply that the justification for obeying the law on the part of investor corporations is an instrumental or pragmatic justification, they must also imply that in appropriate circumstances it is acceptable for them to break the law. Indeed, investors have devoted considerable energy to thwart reforms aimed at making them accountable beyond the bottom line. In 1996, the United States banking industry successfully lobbied Congress to amend the Superfund legislation to obtain a safe harbour from lender liability suits for cleanup of contaminated lands. ${ }^{2}$ Also, the mutual fund industry in North America fiercely resisted regulations to make it publicly disclose how they vote as shareholders. (Davis, Lukomnik and Pitt-Watson, 2006: 73). In other policy domains such as climate change, toxic pollutants and labour standards, the corporate sector has time and again sought to block credible regulations (Beder, 2002).

Yet, as explained earlier, financial institutions and corporations are legal artefacts, which can exist only where legal systems make it possible for them to exist. The private sector can only operate successfully within societies with functioning legal systems. 
Actions that undermine those legal systems will tend to undermine the success of

business itself. A financial institution or corporation that seeks to respect the law only when to do so has instrumental value for itself, is generating policies that directly conflict with the legal framework and practices which are ultimately necessary for the success of that financial institution or corporation. They do not stand apart from society as distinct self justifying organizations. Thus, once we recognize these circumstances, ethical standards enter the picture for reasons already explained.

As the business case is thus an inadequate basis for SRI, the question to be resolved is how can the legal system create a framework to nurture a more ethical and responsible financial sector. The following section explores this issue.

\section{Legal Reforms for Ethical Investment}

The relationship between SRI and the legal system has only begun to be scrutinized recently (Richardson, 2008). Until the current global financial crisis, there has been a widespread assumption among policy-makers and investors that the market is generally efficient and functions best with minimal governmental oversight. Concomitantly, regulators have connected ecological and social problems only to companies that wield operational control over development, such as mining or manufacturing firms, but not to their financial sponsors. While such assumptions are increasingly questioned, it has not yet led to transformative regulation to instil greater accountability of financial institutions. SRI reforms adopted so far have been mainly market-based and informational standards that leave financiers with significant discretion (Richardson, 2007a). And governments' principal response to the financial meltdown of 2008-09 has been huge bail-outs of insolvent banks and investment companies rather than to change fundamentally the way they are regulated to prevent future crises.

Overall, SRI regulation so far commonly involves process standards, including mechanisms for financiers to report their SRI policies, proxy voting activities, and environmental impacts of financial significance. These requirements may enable the assessment, verification and communication of performance and, in theory, thereby put pressure on environmental laggards to change or to reward leaders through competitive market advantages. For example, in the United Kingdom (UK) and several other 
European states, and Australia, occupational pension funds must now disclose any policies they adopt for SRI. ${ }^{3}$ In Canada and the United States, mutual funds must disclose their proxy voting policies and voting records when acting as shareholders. ${ }^{4}$ Yet, financiers may choose not to invest ethically, so long as they disclose that decision. In practice, their mandated disclosures often entail vague, perfunctory statements that reveal little about the rationale or methodology behind SRI policies or the quality of their implementation (Fair Pensions, 2006). In theory, procedural standards could usefully nurture more open and participatory decision-making, as a means of cultivating ethical positions. But there is little evidence to date that these reforms have encouraged such practices.

Consistent with business case SRI, some governments have also introduced economic policy instruments, such as green investment tax concessions (e.g., in the Netherlands), ${ }^{5}$ or environmental liability for financiers (e.g., in the United States). In principle, such measures improve the cost-benefit equation in favour of sustainable development. By appealing to financiers' self-interest, they can provide a powerful incentive for financiers to act responsibly. A 2002 study by KPMG found that the Dutch scheme between 1996 and 2002 had delivered €2.8 billion of investment from 140,000 individual investors in over 2,100 projects. Such results, however, hardly justify legislating SRI primarily through economic incentives. Many environmental and social issues are too complex to be .broken down into discrete targets to be financially rewarded. Setting goals for reducing greenhouse gas emissions is much easier to measure and reward than maintaining biological diversity or the integrity of entire ecosystems.

Normative standards, which can provide substantive principles to guide investment, are not widely availed in SRI governance. In some jurisdictions, national pension funds are obliged to invest responsibly and ethically. These measures have been adopted in France, New Zealand, Norway, and Sweden. For example, the Norwegian Pension Fund is obliged by its governing regulations to "not make investments which constitute an unacceptable risk that the Fund may contribute to unethical acts or omissions, such as violations of fundamental humanitarian principles, serious violations of human rights, gross corruption or severe environmental damages”. ${ }^{6}$ An ethics council guides the fund in discerning ethical investment choices. Based on recommendations of the council, the Norwegian Fund has divested from companies dealing with cluster 
bombs (Lockheed Martin), nuclear weapons components (Boeing), breaches of human rights and labour standards (Walmart), and environmental damage (Freeport). A recent survey of the Norwegian and other public sector funds "highlight[ed] a range of some of the most advanced and creative approaches to responsible investment" (UNEPFI, 2007: 7).

The financial community has also devised its own standards for SRI. A plethora of codes of conduct has emerged in recent years, including the London Principles of Sustainable Finance (2002), Equator Principles (2003), and the United Nations Principles for Responsible Investment (2006). Some codes have also been tailored to specific SRI issues, particularly climate change: these include the Carbon Disclosure Project (2000), Carbon Principles (2008) and the Climate Principles (2008). The track record of financial institutions that have voluntarily committed to such standards is generally less than exemplary. These voluntary codes generally do not require signatories to attain any threshold performance as a condition of joining, nor meet any substantive social or environmental standards afterwards. The codes' principal requirements are procedural, such as periodic reporting and disclosure of activities. The Equator Principles, dealing with project financing, prescribe the most detailed sustainable development standards, and the most credible public reporting and consultation standards; although evidence that some banks continue to sponsor environmentally degrading projects suggests that implementation of the Principles is uneven (Hardenbrook, 2007).

More ambitious ethical charters relevant to the financial sector exist, but they have been largely shunned by investors. The Collevecchio Declaration on Financial Institutions, drafted in 2003 by a coalition of nongovernmental organizations (NGOs), ${ }^{7}$ lists several rigorous standards specifically for financial markets, based on six core principles, namely: sustainability, “do no harm”, responsibility, accountability, transparency, and sustainable markets and governance. For instance, the Declaration's ambitious "commitment to sustainability" principle obliges signatories to "fully integrate the consideration of ecological limits [and] social equity ... into corporate strategies and core business areas (including credit, investing, underwriting, advising), to put sustainability objectives on an equal footing to shareholder maximization and client satisfaction...”. Yet, apart from the California Public Employees' Retirement System, no financial institution has endorsed the Declaration as of August 2009. 
Another ambitious statement of ethics is evoked by the Earth Charter. ${ }^{8}$ It was adopted in 2000 following lengthy consultation mainly held among NGOs, and encouragingly has endorsements from some 3,000 organizations and governments worldwide. The Charter contains several principles relevant for the business sector, including: "[e]nsure that economic activities and institutions at all levels promote human development in an equitable and sustainable manner”. While quite a few business organizations have endorsed the Earth Charter, they have probably done so because the Charter's provisions are so broadly stated that signatories cannot be measurably held to account and the Charter lacks the machinery to enforce compliance.

In the following section, some different legal reforms are considered to promote ethical investment. While the discussion focuses on legal design, it must be stressed that the law does not necessarily have a life of its own. Its influence is contingent on the kind of economic, cultural and political conditions in which it functions. Crucial to the success of legal strategies in this respect are ethical arguments and debates that can help persuade financial institutions and investors to act ethically. Simply prescribing ethical commands would hardly suffice.

\section{Promoting Ethical Investing through Fiduciary Duties}

\section{The ethical and legal baselines}

So how then, should we improve the ethics of ethical investment? How should these ethics be determined and by what means should they be advanced? As previously explained, some ethical issues on the SRI agenda involve highly contentious activities, such as tobacco production or fertility control, where there is widespread societal disagreement. Thus, when the Irish Parliament in 2006 rejected a proposed legislative amendment to require the country’s National Pensions Reserve Fund to invest ethically, one parliamentarian reasoned: “[a] major difficulty in deciding on ethical investment policy is where to draw the line in defining the parameters of the policy, given that there will inevitably be different opinions and intense debate on what constitutes ethical and socially responsible investment” (Parliament of Ireland, 2006: 5). But there are other activities, such as pollution, fishing and deforestation, which by and large are not 
considered intrinsically problematic, but which still cause concern because they occur too much. In other words, the problem is the extent of the activity. These are examples of market failures or tragedies of the commons, which ultimately are as devastating for the economy as the environment. It is these latter concerns that are more amenable to ethical standards and legal regulation to ensure that economic development is conducted sustainably. Breaches of human rights, another concern of many social investors, do not per se involve market failures. Yet, they may also be actionable because there can exist widespread social agreement on the value of some of these rights, such as prohibitions against racial discrimination.

A second important consideration to note at this stage is who are the investors to whom these ethical issues or controversies apply? We can distinguish between individuals who invest on their own behalf (commonly known as "retail investors"), and financial intermediaries, such as pension funds or life insurance companies, which invest on behalf of others. There will always be some room for individuals to choose lawful investments according to their own moral scruples, such as avoiding companies that engage in activities they find personally offensive, whether it be selling alcohol or operating a casino. But where financial institutions manage the assets of millions of people and have the capacity to exert huge economic influence, they must be governed by environmental and social standards that avoid exacerbating the market failures or human rights abuses described above. They should be regarded as institutions with special public responsibilities.

In determining what standards financial intermediaries should follow, they can hardly set their moral compass by the law of the land. If this were so, then if a corporate development such as a mining project is ostensibly lawful, in that the developer has the requisite licences and other regulatory approvals, then presumably it would be perfectly acceptable for an ethical investor to fund that project no matter how environmentally deleterious it was.

Legal theorists have long identified a series of explanations for why the law often fails to supply adequate social, economic and environmental standards that respond to public interests. These include the ability of powerful corporate interests to "capture" the regulatory process to ensure that laws unfavourable to their interests are not enacted or not implemented (Laffont and Tirole, 1991). Another problem is that in some countries, 
particularly emerging economies, the state is weakened by corruption, civil strife, insufficient resources and other factors that undermine its capacity to govern (Brinkerhoff and Brinkerhoff, 2002). Countries such as Congo, Nigeria, Sudan and Pakistan are current examples of weak or "failed states”. It would thus be preposterous to suggest that merely because a mining project in such countries is "lawful" that it is fit for ethical investment. Given that one of the traditional purposes of SRI has been to advance change, to push corporations beyond the letter of the law, it would seem counterproductive to be guided only by the existing legal baseline.

Another reason why existing law alone can hardly be the benchmark for determining the ethical content of SRI is that often it is unclear what "the law" is. Typically, most corporate activities or products are subject to impact assessments, permits, and other regulatory checks where regulators wield significant discretionary power to make decisions on a case-by-case basis. Further, complex interactions between different areas of law may arise; for instance, an emission license does not necessarily shield a polluter from other legal actions such as tort suits. ${ }^{9}$ There is also the role of international law to consider; what may be lawful in an individual nation may run afoul of basic international human rights and environmental standards. In other words, a company or an investor can not simply forecast what is appropriate behaviour by looking at the rule-book; the applicable legal norms arise through a complex, dynamic process involving regulators, courts and other legal actors.

\section{Existing fiduciary law and SRI}

Therefore, ethical investment requires its own legal apparatus that directly targets the financial sector. The fiduciary duties of financial institutions are the most legally significant part of that apparatus, although presently they are generally not conducive to ethical investment. The legal system imposes fiduciary standards on financial intermediaries to invest carefully in the interests of their beneficiaries and in accordance with the purpose of the particular fund. ${ }^{10}$ A fiduciary relationship involves a duty of loyalty, requiring the fiduciary to act in the beneficiaries' sole or best interests (Langbein, 2005). The fiduciary also has a duty of competence, requiring skill and diligence, which 
is usually expressed in investment context as the "prudent investor rule" (Longstreth, 1986).

Fiduciary standards can constrain SRI in principally two ways. First, there is a widespread presumption that the best interests of the beneficiaries of a fund are of a financial character. Some British court rulings such as in Cowan v Scargill ${ }^{11}$ and other cases $^{12}$ suggest pension funds are liable to their beneficiaries for losses if they sacrifice financial returns at the altar of ethical causes. Of course, if the governing deed of a financial institution expressly requires social investment to further a specified mission, then the fiduciary must fulfil the specified criteria unless legislation dictates otherwise. ${ }^{13}$ Investment by charitable foundations can fall into this situation. While the directors of a bank do not owe similar fiduciary duties to the bank’s depositors, they are at least legally accountable to the bank and its shareholders to act financially prudently. ${ }^{14}$

The second seminal way that fiduciary duties frustrate SRI is by relegating fund members to a passive role (Alexander, 1993). Rather than treating beneficiaries in pension plans as self-governing and responsible owners, fiduciary rules reduce them to a largely passive and voiceless status in investment decision-making, merely normally entitled only to be "informed" about how fiduciaries deal with their assets. Unless required by special legislation, fiduciaries need not consult with beneficiaries. They only need to act in their "best interests", though they need not inquire what those best interests are.

Fiduciary duties were first seen as a hindrance in the 1980s during the South African divestment campaign (Troyer, et al., 1985). Today, the impact of fiduciary duties on a much more heterogeneous SRI agenda is debated. The World Economic Forum (2005: 10) has recommended that authorities "[m]odify pension fiduciary rules which discourage or prohibit explicit trustee consideration of social and environmental aspects of corporate performance”. Confidently, a report commissioned by UNEPFI (Freshfields Bruckhaus Deringer, 2005: 13) suggested that "integrating [SRI] considerations into an investment analysis so as to predict more reliably financial performance is clearly permissible and is arguably required in all jurisdictions”. But the Freshfields report, as can be seen from this quotation, narrowly understood SRI as essentially business case SRI. A successor report issued by UNEPFI in 2009, to examine developments in fiduciary law since the Freshfields report, concluded that "some institutional investors 
still appear to be uncertain about the breadth of their discretion to consider [environmental, social and governance] issues” (UNEPFI, 2009: 64). Some legal commentators suggest that many of the practices of the SRI industry today remain of “doubtful legality” (Thornton, 2008: 415) from a fiduciary perspective.

To date, there have been very few reforms to fiduciary duties relevant to SRI. In the United States, Connecticut legislation provides that managers of the State Retirement Plans and Trust Funds may consider the environmental and social implications of investments. ${ }^{15}$ But whether they may do so at the expense of financial returns is unclear. In Canada, Manitoba's Trustee Act was amended in 1995 to permit trustees to consider non-financial criteria in their investment policies, so long as "the trustee exercises the judgment and care that a person of prudence, discretion and intelligence would exercise in administering the property of others". ${ }^{16}$ However, such standards do not require consideration of social and environmental matters; they remain a discretionary consideration. Nor does a discretionary standard allow affected third parties to enforce their interests. There is a difference between taking the interests of other stakeholders into account and owing a duty to those parties. The duty of loyalty that a fiduciary owes remains to the fund's beneficiaries under these reforms. ${ }^{17}$

More stringently, mandatory legislation for corporate social responsibility in the context of company law is not unprecedented. A rare example is the UK's Companies Act of 2006, which comes “close to a stakeholder model of director's duties”, according to Williams and Conley (2007: 354). Section 172(1) of this statute requires the directors of a company in promoting the success of their firm to "have regard" to "the impact of the company's operations on the community and the environment”. Breach of this duty could make a corporate transaction voidable and result in civil liability for directors. Applied to financial institutions, such a standard could help to redefine fiduciary duties of institutional investors along the lines of Hawley and Williams' (2000) “universal owner” thesis. The financial success of institutional investors, with economy-wide portfolios, is unlikely to be insulated from the social and environmental stresses that a single corporation may avoid.

\section{Reforming fiduciary finance}


Reforming fiduciary duties to resolve the conflict between profit maximization and operating within the context of ethical constraints is not straight-forward. Aside from the political problems in mustering support for such a legislated reform, considerable practical difficulties in designing a credible legal standard exist. It would be unworkable if financial institutions were merely accountable to vague prescriptions such as to “promote sustainable development”. Like the broader societal debates about sustainable development, such a general goal would be subject to discretionary interpretations that would allow problematic trade-offs and perfunctory implementation. It would therefore need to be embellished with prophylactic rules. But if they could be successfully redefined, financial institutions that failed to meet them could be subject to various penalties, ranging from damages suits brought by aggrieved fund members to regulatory sanctions including future restrictions on their investment choices or financial penalties to reflect social costs.

Social accounting and sustainability indicators provide metrics that could help quantify social and environmental performance to underpin a new fiduciary standard. But they may be too complex to administer and problematically reduce ethics into a mechanical formula. Social accounting aims to measure the collateral benefits (e.g., public infrastructure, and environmental protection) and costs (e.g., damage to natural resources) of economic activity (Unerman, et al, 2007; Quarter, et al, 2003). Social accountants, however, have yet to devise means to valuate all social or environmental impacts, and this approach if achievable would require fundamental changes to the prevailing Generally Accepted Accounting Principles (GAAP). So far, social accounting has mostly influenced the propagation of satellite, narrative reporting schemes, such as the “management discussion and analysis” sections in corporate financial statements.

Sustainability indicators have likewise remained somewhat of an experimental concept. They allow progress towards sustainability based on certain social, environmental, and other markers to be tracked over time (Bell and Morse, 2008). They can also assist decision-makers by translating ecological, economic, and social data into performance standards, and warning of impending problems. While sustainability indicators can be just as methodologically complex to determine as social accounting metrics, they do not per se require financial quantification. And they do not dictate how underlying performance standards be met. Sustainability indicators for financial 
institutions’ portfolios as a whole have not been adequately designed. One innovative attempt to quantify an important externality of an entire investment portfolio is Trucost's annual "carbon counts" survey, which measures and ranks UK investment funds according to the carbon intensity of their portfolios (a seminal indicator of sustainability). Its evaluation of 185 investment funds in 2007 found that 25 percent of the so-called SRI funds polluted more than the average conventional fund (Trucost, 2007). As for social accounting, some activities or impacts likely cannot be quantified for the purposes of a sustainability indicator. One example is the evaluation of the social equity in the distribution of the benefits and burdens of use of the environment.

These metrics for reforming fiduciary duties would be most appropriate for SRI addressing market failures such as greenhouse gas emissions or toxic pollution, and, somewhat more challengingly, social harms including transgression of basic human rights. But what about the ethical issues where there is no "ethical custom" to guide standards, such as contraception technologies, animal experimentation, or vulgar entertainment? Public opinion is greatly divided on the ethical status of such issues. Some legal scholars thus cite these examples as reasons not to change fiduciary duties. Thornton (2008: 419) argues: “[w]hat is considered to be 'ethical' in investment terms is inherently subjective, imprecise and continually changing with altered societal perspectives: a difficult basis on which to found legal reform”.

In such circumstances, rather than attempt to simplify complex ethical issues and debates into discrete standards, law reformers could less ambitiously alter financial decision-making procedures in order to at least oblige fiduciaries to consider the ethical ramifications of their decisions and to report publicly on their decisions and rationales. While in some jurisdictions pension funds are already required to disclose publicly any SRI policies, presently they generally do not need to disclose how they implement such policies or why they chose such policies. One could even require such disclosures to be audited by third parties, and deficiencies publicly exposed.

Another procedural reform would be to democratize decision-making processes, in the hope of making fiduciaries more aware of the interests of other stakeholders and fostering ethical deliberation with them. Watt (2006: 437) has suggested that fiduciaries could be placed under a legislated duty to consult with their beneficiaries and to consider their opinions when formulating investment policies. As for consulting with other 
stakeholders, already the Equator Principles require signatory banks to consult with local communities who may be affected by projects they plan to finance. One rationale for these consultative mechanisms is that the governing boards of pension trusts or investment funds are typically drawn from a narrow segment of society, and may lack expertise on SRI issues (Gribben and Gitsham, 2006). Nonetheless, the problem with reforms that seek to give a voice to the beneficiaries of a fund or other stakeholders is that the views of a minority may be overridden where there is no consensus of opinion, and the relative weight that fiduciaries attach to the various views cannot be readily scrutinized. Where a fiduciary must consider numerous, conflicting interests without any way of prioritizing among them, any decision taken that is not blatantly self-interested possibly becomes defensible.

One potential remedy might be to accommodate a voice for stakeholders in an external entity, such as a national ethics council. The state could appoint a body of representatives from key constituencies to devise standards for ethical investment. Fiduciaries would receive guidance on difficult ethical questions, avoiding trial and error. Sweden and Norway have already established ethics councils to guide their public pension funds, and in the case of the Norwegian council, it has made recommendations to divest from companies such as Wal-Mart and Barrick Gold, which have been accepted by the fund administrators (Criscione, 2009).

While this article is not designed to provide a comprehensive analysis of other legal reforms that could strengthen the prospects for ethical investment, a few brief comments should be made regarding other potential collateral reforms. Fiduciary duties, no matter how restructured, will not encompass all financial activities. For example, in the retail investment market, mutual funds have much more flexibility in their investment choices and conceivably can cater to any values investors demand including those oppressive to human rights or the environment. Therefore, other kinds of policy tools must be harnessed to capture the diverse array of financial entities and transactions. As a priority, reformers must seek to improve the quality of corporate environmental and social reporting. Having companies report regularly and comprehensively on their environmental and social activities and impacts can help generate reliable information to inform SRI choices (Harte, Lewis and Owen, 1991). Traditionally and still very much today, corporate financial reporting has not reflected the social and environmental costs 
and benefits of business activity (KPMG, 2005). Corporate governance must also be reformed. The importance of democratizing governance within financial institutions has already been noted. Comparable reforms at the corporate level are necessary given that social investors sometimes rely on shareholder advocacy as a means of changing recalcitrant firms from within (Del Guercio and Hawkins, 1999). In some jurisdictions, significant barriers to shareholder activism persist, such as restrictions on the type of issues that can be raised in a shareholder resolution and the passive culture of voting fostered by proxy contest rules (Sarra, 2003). At an international level, states should negotiate agreements setting social and environmental standards for transnational finance. In global economy, SRI governance can hardly continue to rest solely on disparate national standards (Doering, et al., 2002: 54). International-level financial regulation would mitigate a deleterious race to the bottom, as common standards should reduce the incentives for financiers to flee to the most regulatorily benign markets. The existing voluntary international standards, such as the United Nations Principles for Responsible Investment or the Equator Principles, are not sufficiently rigorous to change the status quo.

\section{Conclusions}

While the SRI market is ostensibly flourishing, the financial economy remains largely unchanged. An unresolved tension between the financial and ethical aspirations of SRI persists. Some investors may acknowledge environmental or social problems where they are financially material to the bottom line, but they usually eschew engagement with the moral issues at stake. The business case model of SRI sanguinely transforms the tensions between environmental protection or social justice and profitable investment into a seemingly harmonious relationship. The SRI is loaded with rhetoric how being virtuous can enable one to be prosperous.

Of course, that sustainability and business success can be compatible is not deniable - financiers should benefit from companies that reduce their ecological footprint. The problem is that some financiers masquerading as responsible investors merely tinker with unsustainable practices. Based on a philosophy of financial materiality, the business case may address some environmental and social problems through improved research 
and analysis. However, it cannot accommodate those issues not valued by the market, and existing strategies in this model are unlikely to transform investment "value" to incorporate other non-financial factors. Without demonstrated financial advantage, an investment analysis may advocate delaying or halting measures that mitigate pollution or reducing social inequities, especially in the absence of effective government regulation and stakeholder pressure. In fact, a countervailing business case for intensifying environmentally unsustainably practices will be evaluated.

To keep ensure that all investment is ethical necessitates many changes to SRI regulation. The legal system translates a society's values and expectations into workable policy instruments for implementation. Among the menu of reforms, the reformulation of fiduciary duties is crucial. They define the core goals and processes of decision-making within financial institutions. Through fiduciary duties the traditional concept of "benefit" to investors can be ethically redefined, and thereby financiers steered toward sustainability. If grounded in new forms of social accounting, sustainability indicators, and performance standards, such fiduciary standards could enable the financial sector to address market failures such as climate change. At the same time, we must appreciate that the law needs the assistance of ethical arguments to encourage companies and investors to improve their behaviour. It is a not a one-way relationship wherein the legal system is simply a conduit for pre-determined ethical imperatives. Ethical investment will be resisted if investors regard it simply as a regulatory prescription. The legal system can create spaces for ethical deliberation and ethical arguments that can be used to facilitate behaviour changes when monetary incentives or coercion struggle to succeed.

\section{References}

Alexander, G.: 1993, "Pensions and Passivity”, Law and Contemporary Problems 5(1): 111.

Alexander, K., R. Dhumale, and J. Eatwell: 2006, Global Governance of Financial Systems (Oxford University Press, Oxford). 
Angel, J. and P. Rivoli.: 1997, "Does Ethical Investing Impose a Cost Upon the Firm? A Theoretical Perspective”, Journal of Investing 6(4): 57.

Atkisson, A.: 2006, The Earth Charter and the Business Sector: How a Consensus on Global Values Can Add Values (Earth Charter International, Stockholm).

Bainbridge, S.M.: 2002, Corporation Law and Economics (Foundation Press, New York).

Beder, S.: 2002, Global Spin. The Corporate Assault on Environmentalism (Green Books, Dartington, England).

Bell, S. and S. Morse: 2008, Sustainability Indicators: Measuring the Immeasurable (Earthscan, London).

Brinkerhoff, D.W. and J.M. Brinkerhoff: 2002, “Governance Reforms and Failed States: Challenges and Implications”, International Review of Administrative Sciences 68(4): 511.

Brill, H., J.A. Brill, and C. Feingenbaum: 1999, Investing with Your Values: Making Money and Making a Difference (Bloomberg Press, Princeton).

Case, D.: 2006, "Changing Corporate Behavior through Environmental Management Systems”, William and Mary Environmental Law and Policy Review 31: 7.

Clark, R.: 1986, Corporate Law (Aspen Publishers, New York).

Clark, G.: 2007, "Expertise and Representation in Financial Institutions: UK Legislation on Pension Fund Governance and US Regulation of the Mutual Fund Industry”, Twenty-First Century Society 2(1): 1.

Cosans, C.: 2009, “Does Milton Friedman Support a Vigorous Business Ethics?” Journal of Business Ethics 87(3): 391.

Cragg, W.: 2000, "Human Rights and Business Ethics: Fashioning a New Social Contract”, Journal of Business Ethics 27(1-2): 205.

Cragg, W.: 2004, "Human Rights, Globalization and the Modern Shareholder Owned Corporation” in T. Campbell (ed.), Human Rights and the Moral Responsibilities of Corporate and Public Sector Organisations (Kluwer, Dordrecht), 105.

Criscione, V.: 2009, “Pension Fund Treads a Thorny Path”, Financial Times (16 March), 9.

Daly, H.: 1992, "Allocation, Distribution and Scale: Towards an Economics that is Efficient, Just and Sustainable”, Ecological Economics 6: 185. 
Davis, S., J. Lukomnik and D. Pitt-Watson: 2006, The New Capitalists: How Citizen Investors are Reshaping the Corporate Agenda (Harvard Business School Press, Cambridge).

Del Guercio, D. and J. Hawkins: 1999, "The Motivation and Impact of Pension Fund Activism”, Journal of Financial Economics 52: 293.

Devall, B. and G. Sessions: 2001, Deep Ecology: Living as if Nature Mattered (Gibbs Smith, Layton).

Doering, D., et al.: 2002, Tomorrow's Markets - Global Trends and their Implications for Business (World Resources Institute, Washington DC).

Donaldson, T. and L.E. Preston: 1995, "The Stakeholder Theory of the Corporation: Concepts, Evidence, and Implication”, Academy of Management Review 20(1): 65.

Easterbrook, H. and D.R. Fischel: 1985, "Limited Liability and the Corporation"< University of Chicago Law Review 52: 89.

Elhauge, E.: 2005, "Sacrificing Corporate Profits in the Public Interest”, New York University Law Review 80: 733.

Ellison, R.: 1991, “The Golden Fleece? Ethical Investment and Fiduciary Law”, Trust Law International 5(4): 157.

Eurosif: 2006, Socially Responsible Investment among European Institutional Investors (Eurosif, Paris).

Fair Pensions: 2006, UK Pension Scheme Transparency on Social, Environmental and Ethical Issues (Fair Pensions, London).

Falk, R.1999: Predatory Globalization: A Critique (Polity Press, Cambridge)

French, H.: 1998, Investing in the Future: Harnessing Private Capital Flows for Environmentally Sustainable Development (Worldwatch Institute, Washington $\mathrm{DC})$.

Freshfields Bruckhaus Deringer: 2005, A Legal Framework for the Integration of Environmental, Social and Governance Issues into Institutional Investment (UNEPFI, Geneva).

Gillan, S.L. and L.T. Starks: 1998, "A Survey of Shareholder Activism: Motivation and Empirical Evidence”, Contemporary Finance Digest, Autumn: 2. 
Gilson, R. and R. Kraakman: 1991, "Reinventing the Outside Director: An Agenda for Institutional Investors”, Stanford Law Review 43: 863.

Goodman, S. and T. Little: 2003, The Gap in GAAP: An Examination of Environmental Accounting Loopholes (Rose Foundation, Oakland).

Government Accountability Office (GAO): 2004, Environmental Disclosure: SEC Should Explore Ways to Improve Tracking and Transparency of Information (GAO, Washington DC).

Gray, R., D. Owen, and C. Adams, eds: 1996, Accounting and Accountability: Changes and Challenges in Corporate Social and Environmental Reporting (Prentice Hall International, New Jersey).

Gribben, C. and M. Gitsham: 2006, Will UK Pension Funds Become More Responsible: A Survey of Trustees (UK Social Investment Forum, London).

Gutmann A. and D. Thompson: 2003, "Deliberative Democracy beyond Process”, in J. Fishkin and P. Laslett (eds), Debating Deliberative Democracy (Blackwell Publishing, Oxford), 31.

Hardenbrook, A.: 2007, “The Equator Principles: The Private Financial Sector's Attempt at Environmental Responsibility”, Vanderbilt Journal of Transnational Law 40: 197.

Harte, G., L. Lewis and D. Owen: 1991, "Ethical Investment and the Corporate Reporting Function”, Critical Perspectives on Accounting 12(3): 227.

Hawken, P.: 2004, Socially Responsible Investing (Natural Capital Institute, Sausalito),

Hawley, J., and A. Williams: 2000, The Rise of Fiduciary Capitalism (University of Pennsylvania Press, Philadelphia).

Heremans, D.: 2006, Corporate Governance Issues for Banks. A Financial Stability Perspective (Department of Economics, K.U. Leuven).

Herz, S., A. Vina, and J. Sohn: 2007, Development without Conflict: The Business Case for Community Consent (World Resources Institute, Washington DC).

Hudson, A.: 1999, Principles of Equity and Trusts (Cavendish, London).

Kant, I.: 1999, Metaphysical Elements of Justice, translated and introduced by J. Ladd ( $2^{\text {nd }}$ edition, Hackett Publishing, Indianapolis).

KPMG: 2006, International Survey of Corporate Responsibility Reporting 2005 (KPMG, London). 
KPMG: 2002, Sustainable Profit. An Overview of the Environmental Benefits Generated by the Green Funds Scheme (KPMG, London).

Jänicke M.: 1986, State Failure: The Impotence of Politics in Industrial Society (Polity Press, Cambridge).

Jensen, M.: 2000, A Theory of the Firm: Governance, Residual Claims, and Organizational Forms (Harvard University Press, Cambridge).

Jeucken, M,: 2001, Sustainable Finance and Banking: The Financial Sector and the Future of the Planet (Earthscan, London).

Juravle, C. and A. Lewis: 2008, "Identifying Impediments to SI in Europe: A Review of the Practitioner and Academic Literature”, Business Ethics: A European Review 17(3): 285.

Keeble, J., S. Topiol and S. Berkeley: 2003, "Using Indicators to Measure Sustainability Performance at a Corporate and Project Level”, Journal of Business Ethics 44(2-3): 149.

Klein, N.: 2000, No Logo (Flamingo Harper-Collins, London).

Kozul-Wright, R. and R. Rowthorn: 1998, "Spoilt for Choice? Multinational Corporations and the Geography of International Production”, Oxford Review of Economic Policy 14(2): 74.

Labatt, S. and R. White: 2002, Environmental Finance: A Guide to Environmental Risk Assessment and Financial Products (John Wiley and Sons, New York).

Laffont, J. and J. Tirole: 1991, "The Politics of Government Decision Making: A Theory of Regulatory Capture” Quarterly Journal of Economics 106(4): 1089.

Langbein, J.: 2005 "Questioning the Trust Law Duty of Loyalty: Sole Interest or Best Interest?” Yale Law Journal 114: 929.

Langbein, J. and R.A. Posner: 1980, “Social Investing and the Law of Trusts”, Michigan Law Review 79: 72

Light, A. and H. Rolston III, eds.: 2002, Environmental Ethics: An Anthology (Blackwell, Oxford).

Longstreth, B.: 1986, Modern Investment Management and the Prudent Man Rule (Oxford University Press, Oxford).

Luhmann, N.: 1982, The Differentiation of Society (Columbia University Press, New York). 
Luhmann, N.: 1995, Social Systems (Stanford University Press, Palo Alto).

Macey, J.: 1991, "An Economic Analysis of the Various Rationales for Making Shareholders the Exclusive Beneficiaries of Corporate Fiduciary Duties”, Stetson Law Review 21: 23.

Macey, J. and M. O’Hara: 2003, “The Corporate Governance of Banks”, Economic Policy Review 9(1): 91.

Mackenzie, C.: 1998, “The Choice of Criteria in Ethical Investment”, Business Ethics 7(2): 81.

Marjorie, K.: 2001, The Divine Right of Capital: Dethroning the Corporate Aristocracy (Berrett-Koehler, San Francisco).

Marris, R. and D.C. Mueller: 1980, “The Corporation, Competition and the Invisible Hand”, Journal of Economic Literature 18: 32.

McGeachie, S., M. Kiernan and E. Kirzner: 2005, Finance and the Environment in North America: The State of Play of the Integration of Environmental Issues into Financial Research (Environment Canada, Ottawa).

McMurtry, J.: 1998, The Cancer Stage of Capitalism (Pluto Press, London).

Millennium Ecosystem Assessment Board (MEAB), Living Beyond Our Means: Natural Assets and Human Well-Being. Statement from the Board (MEAB, 2005).

Moodie, D.W. and J.C. Lehr: 2008, "Macro-Historical Geography and the Great Chartered Companies: The Case of the Hudson's Bay Company”, Canadian Geographer 25(2): 267.

Parliament of Ireland, Select Committee on Finance and the Public Service: 2006, Parliamentary Debates (February 23): 44.

Purcell, N.: 2007; Remarks, UNEPFI Global Roundtable, Melbourne, October 24-25..

Quarter, J., L. Mook, and B. Richmond: 2003, What Counts: Social Accounting for Nonprofits and Cooperatives (Prentice Hall, New Jersey).

Redgwell, C.J.: 1997, "Privatisation and Environmental Regulation: Some General Observations'”, Journal of Energy and Natural Resources Law 15: 34.

Reich, R.B.: 2007, Supercapitalism: The Transformation of Business, Democracy, and Everyday Life (Borzoi Books, New York). 
Richardson, B.J.: 2006, "Financing Environmental Sustainability: A New Role for the Law”, in S. Benn and D. Dunphy (eds), Corporate Governance and Sustainability: Challenges for Theory and Practice (Routledge, London), 122.

Richardson, B.J.: 2007a, "Financing Sustainability: The New Transnational Governance of Socially Responsible Investment”, in Yearbook of International Environmental Law (Oxford University Press, New York), 73.

Richardson, B.J.: 2007b, "Do the Fiduciary Duties of Pension Funds Hinder Socially Responsible Investment?” Banking and Finance Law Review 22(2): 145.

Richardson, B.J.: 2008, Socially Responsible Investment Law: Regulating the Unseen Polluters (Oxford University Press, New York).

Sarra, J.: 2003, “The Corporation as Symphony: Are Shareholders First Violin or Second Fiddle?” UBC Law Review 36: 403.

Sassen, S.: 1996, Losing Control? Sovereignty in the Age of Globalization (Columbia University Press, New York).

Schmid-Schönbein, O. and A. Braunschweig: 2000, EPI-Finance 2000; Environmental Performance Indicators for the Financial Industry (E2 Management Consulting, Zurich).

Slapper, G. and S. Tombs: 1999, Corporate Crime (Longman, Harlow, England).

Social Investment Forum (SIF): 2008, 2007 Report on Socially Responsible Investing Trends in the United States (SIF, Washington DC).

Soros, G.: 2008, The New Paradigm for Financial Markets: The Credit Crisis of 2008 and What It Means (Public Affairs, New York).

Soskolne, C. ed.: 2007, Sustaining Life on Earth (Lexington Books, New York).

Sparkes, R.: 2001, “Ethical Investment: Whose Ethics, Which Investment?” Business Ethics: A European Review 10: 194-.

Stewart, R.B.: 2001, “A New Generation of Environmental Regulation?” Capital University Law Review 29: 21.

Stout, L.: 2002, "Lecture and Commentary on the Social Responsibility of Corporate Entities: Bad and Not-So-Bad Arguments for Shareholder Primacy”, Southern California Law Review 75: 189

Sunstein, C.R.: 1990, "Paradoxes of the Regulatory State", University of Chicago Law Review 57: 407. 
Sunstein, C.R.: 1991, “'Administrative Substance”, Duke Law Journal 3: 607.

Teubner, G.: 1987, Juridification of Social Spheres (Walter deGruyter, Berlin).

Teubner, G.: 1998, “Juridification: Concepts, Aspects, Limits, Solutions”, in R. Baldwin, C. Scott, and C. Hood (eds), A Reader on Regulation (Oxford University Press, Oxford), 389.

Thornton, R.: 2008, "Ethical Investments: A Case of Disjointed Thinking”, Cambridge Law Journal 67: 396.

Triolo, P., M. Palmer, and S. Waygood: 2000, A Capital Solution: Faith, Finance and Concern for a Living Planet (Pilkington Press, London).

Troyer, T., W. Slocombe, and R. Boisture: 1985, "Divestment of South Africa Investments: The Legal Implications for Foundations, Other Charitable Institutions, and Pension Funds”, Georgetown law Journal 74: 127.

Trucost. 2007, Carbon Counts 2007: The Carbon Footprint Ranking of UK Investment (Trucost, London).

Unerman, J., J. Bebbington, and B. O'Dwyer (eds): 2007, Sustainability Accounting and Accountability (Routledge, New York).

Union of Concerned Scientists: 1992, World Scientists' Warning to Humanity (http://www.ucsusa.org/ucs/about/1992-world-scientists-warning-to-humanity.html).

United Nations Environment Programme (UNEP): 2004, Use of Economic Instruments in Environmental Policy: Opportunities and Challenges (UNEP, Nairobi).

United Nations Environment Program Finance Initiative (UNEPFI): 2004a. The Materiality of Social, Environmental and Corporate Governance Issues in Equity Pricing (UNEPFI, Geneva).

UNEPFI: 2004b. Generation Lost: Young Financial Analysts and Environmental, Social and Governance Issues. Executive Summary (UNEPFI, Geneva).

UNEPFI: 2006, Show Me the Money: Linking Environmental, Social and Governance Issues to Company Value (UNEPFI, Geneva).

UNEPFI: 2007, Responsible Investment in Focus: How Leading Public Pension Funds are Meeting the Challenge (UNEPFI, Geneva).

UNEPFI: 2009, Fiduciary Responsibility. Legal and Practical Aspects of Integrating Environmental, Social and Governance Issues into Institutional Investment (UNEPFI, Geneva). 
UNEPFI and Mercer: 2007, Demystifying Responsible Investment Performance: A Review of Key Academic and Broker Research on ESG Factors (UNEPFI, Geneva).

Watt, G.: 2006, Trusts and Equity (2nd ed., Oxford University Press, Oxford).

Watts, P.: 2009, Directors' Powers and Duties (forthcoming).

Werhane, P.: 1985, Persons, Rights and Corporations (Prentice-Hall, Englewood-Cliffs, New Jersey).

Williams, C. and J. Conley: 2007, "Triumph or Tragedy: The Curious Path of Corporate Disclosure Reform in the UK”, William and Mary Environmental Law and Policy Review 31(2): 317.

Wolf, R.M.: 2001, “Will the Nation-State Survive Globalization?” Foreign Affairs 80(1): 178.

Wood, S.: 2006, "Voluntary Environmental Codes and Sustainability”, in B.J. Richardson and S. Wood (eds), Environmental Law for Sustainability (Hart Publishing, Oxford), 229.

World Economic Forum (WEF): 2005, Mainstreaming Responsible Investment (WEF, Geneva).

Yeager, P.C.: 1991, The Limits of Law: The Public Regulation of Private Pollution (Cambridge University Press, Cambridge).

\section{End Notes}

1 See http://www.iccr.org/issues/globalwarm/goalsobjectives.php.

2 Asset Conservation, Lender Liability and Deposit Insurance Protection Act, 1996, Pub. L. No. 104-208, 110 Stat. 3009.

$3 \quad$ E.g., UK's Occupational Pension Schemes (Investment) Regulations, 2005: cl. 2(3)(b)(vi)-(3)(c); Australia's Corporations Act, 2001 (Cth), s. 1013D(1)(l); and France's Projet de loi sur l'épargne salariale (February 7, 2001). No. 2001-152, arts. 21, 23.

$4 \quad$ Securities Exchange Commission (SEC), "Disclosure of Proxy Voting Policies and Proxy Voting Records by Registered Management Investment Companies” (SEC, January 31, 2003), 17 CFR Parts 239, 249, 270, and 274; Canadian Securities Administrators (CSA), National Instrument 81106 Investment Fund Continuous Disclosure and Companion Policy 81-106CP (CSA, 2005).

$5 \quad$ The scheme was revamped and extended in 2002 and 2005: Regeling groenprojecten buitenland, Staatscourant 1 (2 January, 2002) 31; Regeling groenprojecten, Staatscourant 131 (11 July, 2005) 13.

$6 \quad$ Issued December 222005 pursuant to Regulation on the Management of the Government Pension Fund, 2004, at: http://odin.dep.no/fin/english/topics/pension_fund/p10002777/guidelines/bn.html. See http://www.foe.org/camps/intl/declaration.html.

Http://www.earthcharter.org.

See, e.g., the cases of Mandrake Management v. Toronto Transit Commission, (1993) 102 D.L.R. 
10

1

12

13

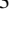

14

15

16

17

(4th); Wheeler v. J.J. Saunders Ltd, [1995] 3 W.L.R. 466.

This fiduciary relationship is a concept of English law by which specific assets are held and managed by the trustee (i.e., the fiduciary) in the interests of the beneficiary (Hudson, 1999). Functionally similar legal arrangements in financial regulation tend to exist in civil law jurisdictions. [1985] 1 Ch. 270.

Martin v City of Edinburgh District Council [1988] SLT 329; Bishop of Oxford v Church Commissioners for England [1992] 1 WLR 1241.

Pension legislation often mandates priority to financial investment returns (eg US's Employee Retirement Income Security Act 1974, s. 404(a)(1)(D).

John Glover, 'Banks and Fiduciary Relationships' (1995) 7(1) Bond Law Review 50.

Conn. Gen. Stat. (2002), s. 3-13d(a).

Trustee Act, S.M. 1995, s. 79.1. In 2005, a similar provision was grafted into Manitoban pension legislation: Pension Benefits Amendment Act, S.M. 2005, s. 28.1(2.2).

[2004] 3 S.C.R. 461, 2004 S.C.C. 68, para. 43. 